\title{
Evolution of aneuploidy: overcoming the original CIN
}

\author{
Zuzana Storchova \\ Department of Molecular Genetics, University of Kaiserslautern, Kaiserslautern 67663, Germany
}

\begin{abstract}
Chromosomal instability (CIN) generates continuously novel aneuploid genomes-unbalanced chromosome combinations that differ from the haploid chromosome set and its multiples. On one hand, this causes problems for cells, as high CIN and aneuploidy impair cellular proliferation by inducing multiple cellular stresses. At the same time, some genomes might provide an advantage under suboptimal conditions. However, what happens to cells that carry a mutation generating extremely high CIN? Are they sentenced to death, or can their instability help them to avert that fate? The elegant work from Ravichandran and colleagues (pp. 1485-1498) in this issue of Genes \& Development exploits budding yeast to shed new light on cellular adaptations to CIN. The study presents exciting findings elucidating forces that shape aneuploid genomes in eukaryotic cells and likely influence karyotypic evolution in cancer cells.
\end{abstract}

Chromosomal instability (CIN) causes variable aneuploi$\mathrm{dy}$, a genomic aberration in which the chromosome number in cells differs from the haploid complement or its multiples. Both CIN and aneuploidy are frequent in various malignancies and correlate with tumor aggressiveness, drug resistance, and poor prognosis for patients (Sansregret and Swanton 2017). At the same time, CIN and aneuploidy induced in vitro lead to a proliferation disadvantage and frequent cell death (Zhu et al. 2018). How cells adapt to CIN and how they can overcome the stresses associated with aneuploidy remain important matters of investigation that will bring new insights to our understanding of adaptation, evolution, and cancer biology.

The budding yeast Saccharomyces cerevisiae provides a versatile tool to study aneuploidy and CIN as well as the cellular adaptations to these conditions. While aneuploidy is mostly detrimental for yeast cells under optimal conditions, it can be advantageous under stress conditions when random mitotic errors generate novel genomic variants that can be selected to match the challenging environment (for review, see Tang and Amon 2013; Bennett et al. 2014).

[Keywords: chromosomes; aneuploidy; chromosomal instability; CIN ; adaptation; chromosomal passenger complex] Corresponding author: storchova@biologie.uni-kl.de Article is online at http://www.genesdev.org/cgi/doi/10.1101/gad.321810. 118 .
Indeed, aneuploidy plays an important role in adaptation to environmental stress, as has been reported in several studies. For example, haploid $S$. cerevisiae strains gain disomy of chromosome IX after 450 generations in rich medium under a constant heat stress of $39^{\circ} \mathrm{C}$ (Yona et al. 2012), while inhibition of Hsp90 results in a frequent gain of chromosome XV (Chen et al. 2012). In pathogenic Candida albicans, treatment with the antibiotic fluconazole selects aneuploid strains with acquired resistance that bring potentially serious consequences for the patients (Selmecki et al. 2006). Thus, in stressful conditions, the advantage gained by specific aneuploidy overcomes the detrimental effects of imbalanced chromosome numbers. Interestingly, when the stressful conditions persist over a prolonged period of time, the aneuploid cells are often eliminated and give way to cells that acquired a less detrimental "solution" by gene mutations (Yona et al. 2012). These and other findings led to the idea that aneuploidy is a fast mutation that can provide a quick, interim solution to various environmental stresses and accelerate phenotypic evolution. However, what happens in cells when the stress conditions are caused by increased levels of chromosome missegregation that generate new aneuploid genomes again and again? How can eukaryotic cells adapt to high levels of CIN?

A new study in this issue of Genes \& Development uses budding yeasts in an elegant experimental setup to address these questions (Ravichandran et al. 2018). Ravichandran et al. (2018) deleted the gene BIR1, a homolog of human survivin and a member of the chromosome passenger complex (CPC). The deletion induces high rates of chromosome missegregation in haploid yeasts and kills most of the cells. However, some cells can survive and adapt to the originally high levels of CIN.

The investigators selected 102 individual survivors that they allowed to further adapt during 10 serial passages. All of these clones showed decreased CIN, improved proliferation, and high levels of aneuploidy with gains of approximately one to six chromosomes. Whole-genome sequencing revealed a plethora of aneuploid karyotypes.

(C) 2018 Storchova This article is distributed exclusively by Cold Spring Harbor Laboratory Press for the first six months after the full-issue publication date (see http://genesdev.cshlp.org/site/misc/terms.xhtml). After six months, it is available under a Creative Commons License (Attribution-NonCommercial 4.0 International), as described at http://creativecommons.org/licenses/by-nc/4.0/. 
Although variable, these aneuploidies were not random, as preferential complex karyotypes with gains of specific chromosomes were observed. Point mutations also occurred during the passaging but did not appear to contribute to the adaptation. Importantly, an early step in adaptation to high CIN was its reduction. The investigators found that in $94 \%$ of the clones, this was achieved by genetic complementation of the BIR1 deletion via the gain of chromosome II, which carries a gene coding for another CPC subunit, Sli15. The investigators validated that the gain of chromosome II is beneficial because of the SLI15 gene by performing an elegant experiment: When an additional copy of SLI15 was inserted on chromosome $\mathrm{V}$ prior to BIR1 deletion, the frequency of chromosome II disomy arising during the in vitro evolution was drastically reduced. This is an important finding, confirming previous observations that high CIN levels are not compatible with survival. Moreover, it suggests that stabilizing the advantageous karyotype might be as important as the original CIN that instigated the genome evolution.

Analysis of the chromosomal combinations that were obtained revealed both negative and positive selection pressures against individual chromosomes and their combinations, a phenomenon that the investigators called chromosome copy number interactions (CCNI). The optimal karyotypes and the CCNI differed in haploid or diploid strains, although the initial insult-high CIN caused by BIR1 deletion-remained the same. CCNI likely also shapes the karyotypes of cancer cells, as demonstrated by the analysis of chromosome pair co-occurrences in five different cancer types from The Cancer Genome Atlas. While the causes of CCNI remain to be elucidated, it is conceivable that synthetic interactions of genes carried on the individual chromosomes will play an important role.

Campbell and colleagues (Ravichandran et al. 2018) also demonstrate striking time-dependent effects on aneuploidy patterns. This is at least partially caused by the fact that while certain aneuploidies exhibit an early benefit during evolution, they will lose their advantages as the cell populations further adapt. For example, the gain of chromosome $\mathrm{X}$ was frequent in early time points but was no longer observed after additional passages. The early advantage of chromosome $\mathrm{X}$ and its subsequent "fall into disgrace" must reflect the physiological changes of the evolving yeast cells because the culture conditions did not change during the experiment. Despite different starting points and different "routes" of adaptation, the selection of the most "optimal" karyotype was observed with time, as the vast majority of the independently grown clones converged on the same karyotype after an additional 200 generations in liquid medium.

Thus, aneuploid karyotypes that support survival in stress environments not only are affected by the environmental selection pressure but also reflect the endogenous stress and the synthetic genetic interactions between the individual chromosomes. Moreover, the forces that shape the genomes change in time, continuously creating new challenges. The findings demonstrate that there are multifaceted forces that affect selection of specific karyotypes and phenotypes in chromosomally unstable eukaryotic cells. Ravichandran et al. (2018) provided us with a new valuable tool for further analysis of these phenomena.

\section{References}

Bennett RJ, Forche A, Berman J. 2014. Rapid mechanisms for generating genome diversity: whole ploidy shifts, aneuploidy, and loss of heterozygosity. Cold Spring Harb Perspect Med 4: a019604. doi:10.1101/cshperspect.a019604

Chen G, Bradford WD, Seidel CW, Li R. 2012. Hsp90 stress potentiates rapid cellular adaptation through induction of aneuploidy. Nature 482: 246-250. doi:10.1038/nature10795

Ravichandran MC, Fink S, Clarke MN, Hofer FC, Campbell CS. 2018. Genetic interactions between specific chromosome copy number alterations dictate complex aneuploidy patterns. Gene Dev (this issue). doi:10.1101/gad.319400.118

Sansregret L, Swanton C. 2017. The role of aneuploidy in cancer evolution. Cold Spring Harb Perspect Med 7: a028373. doi:10.1101/cshperspect.a028373

Selmecki A, Forche A, Berman J. 2006. Aneuploidy and isochromosome formation in drug-resistant Candida albicans. Science 313: 367-370. doi:10.1126/science.1128242

Tang YC, Amon A. 2013. Gene copy-number alterations: a costbenefit analysis. Cell 152: 394-405. doi:10.1016/j.cell.2012. 11.043

Yona AH, Manor YS, Herbst RH, Romano GH, Mitchell A, Kupiec M, Pilpel Y, Dahan O. 2012. Chromosomal duplication is a transient evolutionary solution to stress. Proc Natl Acad Sci 109: 21010-21015. doi:10.1073/pnas.1211150109

Zhu J, Tsai H-J, Gordon MR, Li R. 2018. Cellular stress associated with aneuploidy. Dev Cell 44: 420-431. doi:10.1016/ j.devcel.2018.02.002 


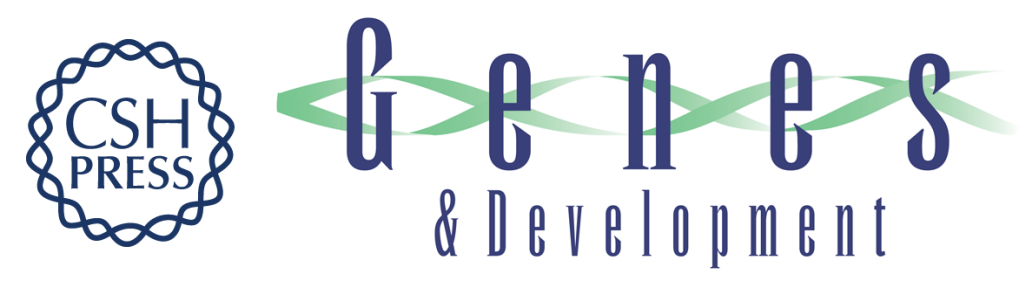

\section{Evolution of aneuploidy: overcoming the original CIN}

\section{Zuzana Storchova}

Genes Dev. 2018, 32:

Access the most recent version at doi:10.1101/gad.321810.118

\section{Related Content Genetic interactions between specific chromosome copy number alterations dictate complex aneuploidy patterns \\ Madhwesh C. Ravichandran, Sarah Fink, Matthew N. Clarke, et al. \\ Genes Dev. December , 2018 32: 1485-1498}

References This article cites 8 articles, 5 of which can be accessed free at:

http://genesdev.cshlp.org/content/32/23-24/1459.full.html\#ref-list-1

Articles cited in:

http://genesdev.cshlp.org/content/32/23-24/1459.full.html\#related-urls

Creative This article is distributed exclusively by Cold Spring Harbor Laboratory Press for the first Commons

License

six months after the full-issue publication date (see

http://genesdev.cshlp.org/site/misc/terms.xhtml). After six months, it is available under a Creative Commons License (Attribution-NonCommercial 4.0 International), as described at http://creativecommons.org/licenses/by-nc/4.0/.

Email Alerting Receive free email alerts when new articles cite this article - sign up in the box at the top Service right corner of the article or click here.

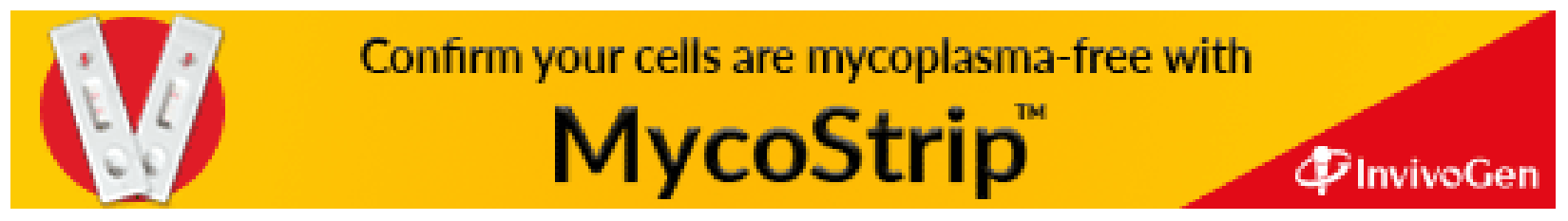

